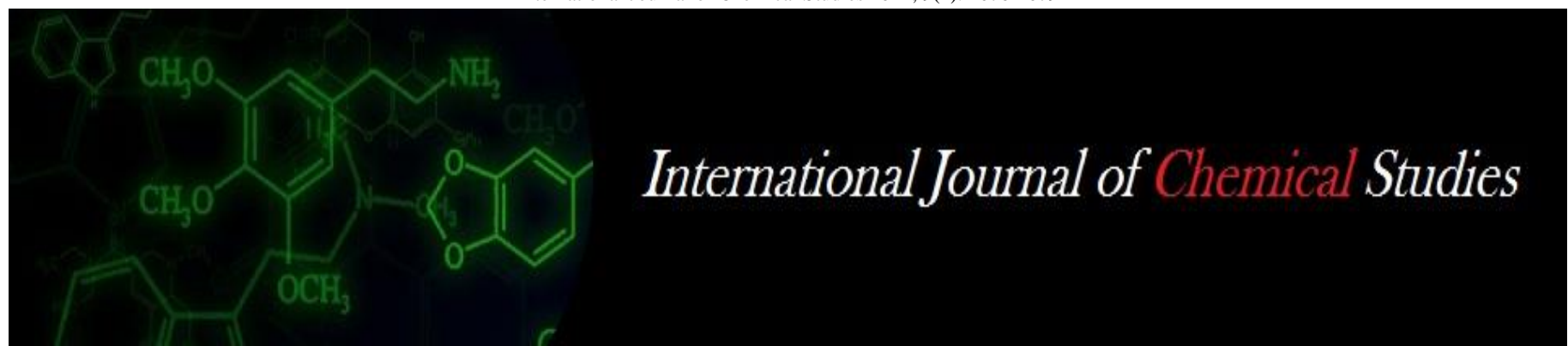

P-ISSN: 2349-8528

E-ISSN: 2321-4902

www.chemijournal.com

IJCS 2021; 9(1): 2076-2079

(C) 2021 IJCS

Received: 17-11-2020

Accepted: 29-12-2020

\section{Pramod Kuma}

Department of Agrometeorology

(COA), Indira Gandhi Krishi

Vishwavidyalaya, Raipur,

Chhattisgarh, India

\section{GK Das}

Department of Agrometeorology

(COA), Indira Gandhi Krishi

Vishwavidyalaya, Raipur,

Chhattisgarh, India

\section{Deepak Lal}

Department of Agrometeorology (COA), Indira Gandhi Krishi

Vishwavidyalaya, Raipur,

Chhattisgarh, India

\section{Yamlesh Nishad}

Department of Agrometeorology (COA), Indira Gandhi Krishi

Vishwavidyalaya, Raipur,

Chhattisgarh, India
Corresponding Author:

\section{umai}

Department of Agrometeorology

(COA), Indira Gandhi Krishi

Vishwavidyalaya, Raipur,

Chhattisgarh, India

\section{Effect of weather parameter on growth and development of wheat under different growing environment}

\author{
Pramod Kumar, GK Das, Deepak Lal and Yamlesh Nishad
}

DOI: https://doi.org/10.22271/chemi.2021.v9.i1ac.11530

\begin{abstract}
The present investigation entitled "Effect of weather parameter on growth and development of wheat under different growing environment" was carried out during Rabi seasons of 2016-17 at Research and Instructional Farm of Indira Gandhi Krishi Vishwavidyalaya, Raipur to examine to validate the results of crop weather relationship of different wheat varieties grown under different growing environments in factorial Randomized Block Design. Some of the important points that emerged from the study are summarized in the present chapter. Among the growth parameters plant height recorded significantly higher in early date of sowing i.e. $1^{\text {st }}$ December as compared to other growing environments (sowing on $11^{\text {th }}$ and $12^{\text {th }}$ December). The interaction of date of sowing with different variety of wheat crop were founds significantly influenced on plant height of crops at 40 DAS and 100 DAS stages. Significantly maximum number of leaves per plant was found with $1^{\text {st }}$ December of sowing. The interaction effect of different date of sowing and varieties were found significant at 60 DAS. Number of tillers per plants were found significantly influenced due to different date of sowing and different variety at $40 \mathrm{DAS}$. At 20 and 80 DAS plant accumulated significantly higher value of dry matter in crop sown on $1^{\text {st }}$ December 2016.
\end{abstract}

Keywords: Growth and development, mustard crop, growing environments and weather

\section{Introduction}

Wheat is the world's number one cereal crop after rice, grown under diverse agro-climatic conditions, contributing nearly one-third of total food grains production. This grown is not only in the temperate zone but also in tropical and sub tropical zone tropical and sub-tropical zones. Three main species commonly grown in the world including India are the common wheat (Triticum aestivum), Marconi or durum wheat (Triticum durum) and emmer wheat (Triticum dicoccum) maximum area are covered by Triticum aestivum out of 3 species. In India, more than $80 \%$ of the total wheat area is under this species where as $12 \%$ and $1 \%$ area under Marconi and emmer wheat. (Draganka et al, 2004) ${ }^{[2]}$. In Chhattisgarh, wheat is sown in an area of 0.171 million hectares out of which 0.063 million hectare area is irrigated and 0.108 million hectare area is unirrigated, with the total production of 181000 metric tons and productivity $1140 \mathrm{~kg} \mathrm{ha}^{-1}$ (Anonymous, 2010) ${ }^{[1]}$.

In Chhattisgarh, wheat is grown mostly under irrigated conditions in a rice based cropping system. The sowing of wheat is often delayed due to delay in harvesting of medium and late duration rice varieties. Late sown wheat crop faces high temperature during grain filling and ripening phases which is one of the major causes of stunted growth and low productivity of wheat in this area. Time of sowing is one of the most important factors which govern the crop phenological development and total biomass production along with the efficient conversion of biomass into economic yield. Delayed sowing of the wheat crop is exposed to sub-optimal temperatures at the establishment and supra-optimal temperatures at reproductive phases resulting into reduction of not only crop duration but also the yield (Sardana et al., 1999) ${ }^{[4]}$.

\section{Material and Methods}

The present study entitled "Effect of weather parameter on growth and development of wheat under different growing environment" was conducted during the Rabi season of 2016-17. 
The experimental details, prevailing weather conditions, materials used and techniques adopted during the course of the investigation are briefly presented in this chapter. The field experiment was carried out at the Research and Instructional farm of Indira Gandhi Krishi Vishwavidyalaya; Raipur situated in Eastern Central part of Chhattisgarh at latitudes of $21^{0} .16^{\prime} \mathrm{N}$, longitude $81^{0} .36^{\prime} \mathrm{E}$ and altitude 289.5 $\mathrm{m}$ above mean sea level. The general climatic condition of Raipur is classified as sub-humid with mean annual rainfall of about $1188 \mathrm{~mm}$ out of which 85 percent rainfall is received during monsoon (June to September). During Rabi, (December to February) only 33.8 rainfall is received and hence wheat is mostly grown under irrigated conditions. The soil of the experimental field was sandy loam with moderately course texture of Inceptisol group locally known as "Matasi."

\section{Observations recorded}

1. Plant population: To record the observation on plant population 3 sample plots $01 \mathrm{~m}^{2}$ area each was randomly selected in each treatment. The number of plants in each quadrate was counted carefully at 20 days after sowing and average were worked out.

2. Plant height $(\mathbf{c m})$ : Five randomly selected plants from each plot were taken at 20 days intervals starting from 20 days after sowing (DAS) till maturity. The plant height was measured from base of the plant to tip of the longest leaf. The mean height was worked out by dividing the summation by five.

3. Number of leaves: To record the observation for number of leaves 5 sample randomly selected in each treatment. The number of leaves per plants was counted carefully at 20 DAS at an interval of 20 days. The mean number as haves per plant was work out by dividing five in total value.

4. Number of Tillers: To record the observation number of tillers were 5 sample randomly selected in each treatment. The number of tiller per plant was counted carefully at 20 days after sowing at an interval starting of 20 days. The mean number of tiller per plant was work out by dividing five in to total value.

5. Dry matter production: The dry weight was recorded at 20 days interval from 40 DAS to maturity by selecting five plants each time. These plants were oven dried at $60^{\circ} \mathrm{C}$ and average dry matter production per plant was worked out. This was multiplied by the average number of plants $/ \mathrm{m}^{2}$ to obtain the dry matter production per $\mathrm{m}^{2}$.

\section{Results and Discussion Growth parameters \\ 1. Plant population}

The data summarizing the plant population per unit area under different dates of sowing and varieties are shown in Table 1. It can be noted from the table that both factor including their interaction effect were found non-significant. In general highest plant population was observed in crop sown on first $\mathrm{D}_{1}$ ( $1^{\text {st }}$ December $)$ (182) followed by $\mathrm{D}_{3}\left(21^{\text {st }}\right.$ December $)$ (174) and lowest plant population was found under $D_{2}\left(11^{\text {th }}\right.$ December) sown crop. The highest plant population was recorded by variety Ratan (178.96) followed by GW-366 (171) and lowest plant population was recorded under GW273 (163). The plant population in all treatment was uniform might be due to seed was placed in propar depth by dibbling method and favourable temperature favars to uniform germination.

Table 1: Plant population $\left(\mathrm{m}^{-2}\right)$ of wheat varieties as influenced by different sowing dates

\begin{tabular}{|c|c|c|c|c|c|}
\hline & & $D_{1-1}{ }^{\text {st }}$ December & $D_{2}-11^{\text {th }}$ December & D_-21 $^{\text {st }}$ December & Mean \\
\hline \multicolumn{2}{|c|}{$\mathrm{V}_{1}$ - Ratan } & 178 & 184 & 173 & 178 \\
\hline$V_{2}$ & - GW-273 & 196 & 126 & 166 & 163 \\
\hline $\mathrm{V}_{3}$ & $-\mathrm{GW}-366$ & 172 & 159 & 182 & 171 \\
\hline \multicolumn{2}{|c|}{ Mean } & 182 & 156 & 174 & \\
\hline & & S.Em \pm & $\mathrm{CD}(p=0.05)$ & & \\
\hline $\mathrm{D}$ & & 12.32 & $(\mathrm{NS})$ & & \\
\hline $\mathrm{V}$ & & 12.32 & $(\mathrm{NS})$ & & \\
\hline \multicolumn{2}{|c|}{$\mathrm{DXV}$} & 21.33 & $(\mathrm{NS})$ & & \\
\hline
\end{tabular}

* Significant at $5 \%$ level; ** significant at $1 \%$ level

\section{Plant height}

The data on plant height influence by various treatments are presented in Table 2. Plant height was differed significantly due to different growing environments at all growth stages. At 20 DAS, significantly highest plant height was recorded with $\mathrm{D}_{3} 21^{\text {st }}$ December $(21.4 \mathrm{~cm})$ followed by $\mathrm{D}_{1} 1^{\text {st }}$ December $\left(20.7 \mathrm{~cm}\right.$.) and lowest plant height was recorded in $\mathrm{D}_{2} 11^{\text {th }}$ December growing $(17.0 \mathrm{~cm})$. At 40 DAS, significantly highest plant height was recorded with $\mathrm{D}_{2}\left(11^{\text {th }}\right.$ December $)$ growing environments $(37.1 \mathrm{~cm})$ followed by $\mathrm{D}_{3}\left(21^{\text {st }}\right.$ December) growing environments $(35.7 \mathrm{~cm}$.) where as lowest plant height was recorded with $\mathrm{D}_{1}\left(1^{\text {st }}\right.$ December $)$ growing environments $(33.8 \mathrm{~cm})$. At 60 DAS significantly highest plant height $(68.0 \mathrm{~cm})$ was noticed in $\mathrm{D}_{1}\left(1^{\text {st }}\right.$ December $)$ growing environments than $\mathrm{D}_{3}\left(21^{\text {st }}\right.$ December $)$ growing environments $(67.72 \mathrm{~cm})$ both were significantly different and lowest plant height was recorded under $\mathrm{D}_{2}\left(11^{\text {th }}\right.$ December $)$ growing environments $(66.0 \mathrm{~cm})$. Plant height seems to be a combination of genetic trait as affected by environmental conditions. At 80 DAS and 100 DAS the significantly highest plant height was recorded with $\mathrm{D}_{1}\left(1^{\text {st }}\right.$ December $)$ growing environments $(86.6 \mathrm{~cm})$ followed by $\mathrm{D}_{2}\left(11^{\text {th }}\right.$ December $)$ growing environments $(80.4 \mathrm{~cm}$.) and the lowest plant height was recorded with $\mathrm{D}_{3}\left(21^{\text {st }}\right.$ December $)$ growing environments $(73.3 \mathrm{~cm})$. The response of variety under different growing environment was non-significant. However in general the maximum plant height recorded by GW-366 at all stages of observation except at early stage in 20 days where in GW-273 responded well over other variety trended. The interaction between varieties and dates of sowing showed the significant difference at $5 \%$ level of significance at 40 DAS and 80 DAS. Interaction effect was found non-significant at all the stage of observation except the required recorded at 40 and 100 DAS. 
Table 2: Effect of different growing environment on plant height $(\mathrm{cm})$ of wheat varieties at 20 days intervals

\begin{tabular}{|c|c|c|c|c|c|c|}
\hline \multicolumn{2}{|c|}{ Treatments } & 20 DAS & 40 DAS & 60 DAS & 80 DAS & 100 DAS \\
\hline \multicolumn{7}{|c|}{ Dates of sowing } \\
\hline \multicolumn{2}{|c|}{$\mathrm{D}_{1}-01$ December } & 20.76 & 33.82 & 68.06 & 86.62 & 87.63 \\
\hline \multicolumn{2}{|c|}{$\mathrm{D}_{2}$ - 11 December } & 17.05 & 37.11 & 66.09 & 80.46 & 81.12 \\
\hline $\mathrm{D}_{3}$ & - 21 December & 21.45 & 35.58 & 67.72 & 73.38 & 75.79 \\
\hline \multicolumn{2}{|c|}{ S.Em \pm} & 0.54 & 0.63 & 1.07 & 0.94 & 0.80 \\
\hline \multicolumn{2}{|c|}{$\mathrm{CD}(p=0.05)$} & $1.62 * *$ & $1.88 * *$ & $(\mathrm{NS})$ & $2.81 * *$ & $2.41 * *$ \\
\hline \multicolumn{7}{|c|}{ Varieties } \\
\hline V1 & - Ratan & 19.57 & 35.68 & 66.61 & 79.24 & 81.19 \\
\hline V2 & $-\mathrm{GW}-273$ & 19.92 & 34.78 & 65.97 & 79.88 & 81.33 \\
\hline $\mathrm{V}_{3}$ & - GW-366 & 19.76 & 36.06 & 69.28 & 81.35 & 82.02 \\
\hline \multicolumn{2}{|c|}{ S.Em \pm} & 0.54 & 0.63 & 1.07 & 0.94 & 0.80 \\
\hline \multicolumn{2}{|c|}{$\mathrm{CD}(p=0.05)$} & $(\mathrm{NS})$ & (NS) & (NS) & $(\mathrm{NS})$ & (NS) \\
\hline \multicolumn{7}{|c|}{ Interaction D X V } \\
\hline \multicolumn{2}{|c|}{ S.Em \pm} & 0.94 & 1.09 & 1.74 & 1.62 & 1.39 \\
\hline \multicolumn{2}{|c|}{$\mathrm{CD}(p=0.05)$} & $(\mathrm{NS})$ & $3.25 *$ & $(\mathrm{NS})$ & $(\mathrm{NS})$ & $4.17 *$ \\
\hline
\end{tabular}

* Significant at $5 \%$ level; ** significant at $1 \%$ level

\section{Number of leaves}

The number of leaves/plant of different wheat varieties as influenced by different sowing dates are presented in Table 3. The number of leaves/plant was found significantly highest in crop sown on $\mathrm{D}_{1}\left(1^{\text {st }}\right.$ December $)$ followed by $\mathrm{D}_{2}\left(11^{\text {th }}\right.$ December) sown crop at 20 DAS. At 40 DAS it was rapidly increased and significantly highest Number of leaves recorded from $\mathrm{D}_{2}\left(11^{\text {th }}\right.$ December) growing environments followed by $\mathrm{D}_{1}\left(1^{\text {st }}\right.$ December $)$ and $\mathrm{D}_{3} \quad\left(21^{\text {st }}\right.$ December $)$ growing environments. Among different growing environment and significantly highest number of leaves per plant was observed under $\mathrm{D}_{1}\left(1^{\text {st }}\right.$ December) growing environment at 60 DAS. The number of leaves/plant decreased with advancement of crop growth and similar trend was observed at 80 and 60 DAS also. The number of leaves per plant influenced by the different wheat varieties as observed highest in Ratan compared to GW-366 and GW-273 at 40 DAS but it was decreased in advancing stages. The increase in the number of leaves per plant in delayed sowing conditions was very slow in all the varieties. Solanki (2014) ${ }^{[5]}$ observed that the magnitude of reduction in the number leaves was more due to increasing in minimum temperature.

Table 3: Number of leaves/plant of wheat varieties as influenced by different dates of sowing

\begin{tabular}{|c|c|c|c|c|c|}
\hline Treatments & 20 DAS & 40 DAS & 60 DAS & 80 DAS & 100 DAS \\
\hline \multicolumn{6}{|l|}{ Dates of sowing } \\
\hline $\mathrm{D}_{1}$ - 01 December & 4 & 11 & 8 & 8 & 6 \\
\hline $\mathrm{D}_{2}-11$ December & 4 & 13 & 9 & 6 & 5 \\
\hline $\mathrm{D}_{3}-21$ December & 3 & 11 & 8 & 5 & 4 \\
\hline S.Em \pm & 0.143 & 0.62 & 0.44 & 0.34 & 0.27 \\
\hline $\mathrm{CD}(p=0.05)$ & $0.427^{*}$ & $1.871 *$ & $1.326 * *$ & $1.028 * *$ & $0.821 * *$ \\
\hline \multicolumn{6}{|l|}{ Varieties } \\
\hline$\left(\mathrm{V}_{1}\right)$ Ratan & 3 & 13 & 8 & 8 & 5 \\
\hline$\left(V_{2}\right) G W-273$ & 3 & 11 & 7 & 7 & 5 \\
\hline$\left(V_{3}\right) G W-366$ & 3 & 12 & 7 & 7 & 5 \\
\hline S.Em \pm & 0.14 & 0.62 & 0.44 & 0.34 & 0.27 \\
\hline $\mathrm{CD}(p=0.05)$ & $(\mathrm{NS})$ & $(\mathrm{NS})$ & $(\mathrm{NS})$ & $(\mathrm{NS})$ & $(\mathrm{NS})$ \\
\hline \multicolumn{6}{|l|}{ Interaction D X V } \\
\hline S.Em \pm & 0.24 & 1.08 & 0.76 & 0.59 & 0.47 \\
\hline $\mathrm{CD}(p=0.05)$ & (NS) & (NS) & $2.296 * *$ & (NS) & (NS) \\
\hline
\end{tabular}

* Significant at $5 \%$ level; ** significant at $1 \%$ level

\section{Number of tillers}

The numbers of tillers were recorded under various treatments and subjected to statistical analysis indicates that there were significant a variety was observed for growing environment where varieties of interaction were found non significant. It quite clear from the table 4 . that sowing of wheat on $D_{1}\left(1^{\text {st }}\right.$ December) recorded significantly higher no. of tillers plant over other date of sowing similarly trend was recoreded during all the stage of observations.. The average no. of tillers per plant was 4 to 7 under various treatment. This might be due to favourable weather parameters during its growth period. Similar tread recorded under all the stages. Patel et al. (2009) reported that the duration of the reproductive period in all the four varieties was related with mean maximum, minimum and average temperature during the reproductive period, i.e., 50 per cent flowering to maturity.

Table 4: Number of tillers per plant of wheat varieties as influenced by different date of sowing

\begin{tabular}{|c|c|c|c|c|}
\hline Treatments & 40 DAS & 60 DAS & 80 DAS & 100 DAS \\
\hline Dates of sowing & & & & \\
\hline$D_{1}-01$ December & 5 & 7 & 6 & 7 \\
\hline$D_{2}-11$ December & 4 & 6 & 6 & 6 \\
\hline$D_{3}-21$ December & 4 & 6 & 0.30 & 6 \\
\hline S.Em+- & 0.22 & 0.31 & 0.31 \\
\hline
\end{tabular}




\begin{tabular}{|c|c|c|c|c|}
\hline CD $(p=0.05)$ & 0.67 & 0.94 & 0.92 & \\
\hline Varieties & & & 6 & \\
\hline$\left(\mathrm{V}_{1}\right)$ Ratan & 5 & 6 & 7 & 6 \\
\hline$\left(\mathrm{V}_{2}\right)$ GW-273 & 4 & 7 & 6 & 7 \\
\hline$\left(\mathrm{V}_{3}\right) \mathrm{GW}-366$ & 4 & 6 & 0.30 & 6 \\
\hline S.Em+- & 0.22 & 0.31 & $(\mathrm{NS})$ & \\
\hline CD $(p=0.05)$ & 0.67 & $(\mathrm{NS})$ & & \\
\hline Interaction D X V & & & 0.31 \\
\hline S.Em+- & 0.38 & 0.54 & & 0.54 \\
\hline CD $(p=0.05)$ & $(\mathrm{NS})$ & $(\mathrm{NS})$ & $(\mathrm{NS})$ & $(\mathrm{NS})$ \\
\hline
\end{tabular}

Significant at $5 \%$ level; $* *$ significant at $1 \%$ level

\section{Dry matter production}

The accumulated dry matter were recorded at an interval of 20 days from sowing to maturity under various treatments are shown in Table 5 . The highest value of dry matter obtained at 20 DAS $\left(17.63 \mathrm{~g} / \mathrm{m}^{2}\right)$ under $\mathrm{D}_{1}\left(1^{\text {st }}\right.$ December $)$ sowing, 40
DAS, $\left(129.31 \mathrm{~g} / \mathrm{m}^{2}\right)$ at $\mathrm{D}_{3}\left(21^{\text {st }}\right.$ December $)$ sowing, $60 \mathrm{DAS}$ $\left(598.22 \mathrm{~g} / \mathrm{m}^{2}\right)$ at $\mathrm{D}_{2}\left(11^{\text {th }}\right.$ December $), 80$ DAS $\left(1785.97 \mathrm{~g} / \mathrm{m}^{2}\right)$ $\mathrm{D}_{1}\left(1^{\text {st }}\right.$ December $)$ sowing and 100 DAS was $\left(2384.23 \mathrm{~g} / \mathrm{m}^{2}\right)$ under $\mathrm{D}_{2}\left(11^{\text {th }}\right.$ December $)$ sowing. The effect of varieties interaction of both the factor non-significant.

Table 5: Dry matter production $\left(\mathrm{g} / \mathrm{m}^{2}\right)$ of wheat varieties at 20 days interval under different growing environments

\begin{tabular}{|c|c|c|c|c|c|}
\hline Treatments & 20 DAS & 40 DAS & 60 DAS & 80 DAS & 100 DAS \\
\hline \multicolumn{6}{|l|}{ Dates of sowing } \\
\hline $\mathrm{D}_{1}-01$ December & 17.63 & 120.29 & 596.20 & 1785.97 & 2188.66 \\
\hline $\mathrm{D}_{2}-11$ December & 13.25 & 118.70 & 598.22 & 1569.76 & 2384.43 \\
\hline$D_{3}-21$ December & 15.43 & 129.31 & 542.50 & 1659.51 & 2300.86 \\
\hline S.Em \pm & 1.02 & 6.53 & 43.13 & 86.31 & 101.55 \\
\hline $\mathrm{CD}(p=0.05)$ & $3.05 *$ & (NS) & (NS) & (NS) & (NS) \\
\hline \multicolumn{6}{|l|}{ Varieties } \\
\hline$\left(\mathrm{V}_{1}\right)$ Ratan & 14.66 & 121.75 & 619.29 & 1669.84 & 2327.67 \\
\hline$\left(V_{2}\right) G W-273$ & 14.69 & 118.39 & 667.47 & 1715.00 & 2375.01 \\
\hline$\left(V_{3}\right) G W-366$ & 16.95 & 128.16 & 607.47 & 1630.39 & 2426.61 \\
\hline S.Em \pm & 1.02 & 6.53 & 43.13 & 86.31 & 101.55 \\
\hline $\mathrm{CD}(p=0.05)$ & (NS) & (NS) & (NS) & (NS) & $(\mathrm{NS})$ \\
\hline \multicolumn{6}{|l|}{ Interaction D X V } \\
\hline S.Em \pm & 110.65 & 11.32 & 74.70 & 149.50 & 175.89 \\
\hline $\mathrm{CD}(p=0.05)$ & (NS) & (NS) & (NS) & (NS) & (NS) \\
\hline
\end{tabular}

Significant at $5 \%$ level; $* *$ significant at $1 \%$ level

\section{Reference}

1. Anonymous. Annual report Department of Agriculture and Cooperation Ministry of agriculture Government of India Krishi Bhawan, New Delhi-110001 2010.

2. Draganska E, Kuchar L, Szwejkowski Z. Weather-crop model selection by Cross Validation test for winter wheat cultivated in North-Eastern Poland. Acta-Scientiarum Polonorum-Agricultura 2004;3(1):29-36.

3. Patel SR, Thakur DS, Lal N. Yield and nutrient uptake of wheat (Triticum aestivum) varieties under different sowing dates. Indian Journal of Agronomy 1999;44(4):733-737.

4. Sardana V, Sharma SK, Randhawa AS. Performance of wheat cultivars under different sowing dates and levels of nitrogen under rainfed condition. Annals of Agricultural Research 1999;20(1):60-63.

5. Solanki NS. Response of wheat (Triticum aestivum) under varying weather environment. Archives, XXXVIII8/W3 Workshop Proceedings: Impact of Climate Change on Agriculture 2009;3(2):50-55 